\title{
General and specific combining ability in tropical winter cauliflower
}

\author{
Felipe M Arashida ${ }^{1}$; Wilson R Maluf'; Regis C Carvalho \\ ${ }^{1}$ Sakata Seed Sudamerica, Bragança Paulista-SP, Brasil; felipe.arashida@sakata.com.br; ${ }^{2}$ Universidade Federal de Lavras (UFLA), \\ Lavras-MG, Brasil; wrmaluf@ufla.br; regisccarvalho@hotmail.com
}

\begin{abstract}
Few Brazilian cauliflower cultivars have shown to be adapted to tropical winter conditions. In addition, studies to obtain hybrids adapted to our winter conditions, from breeding lines originating from tropical regions, are scarce. The objective of this work was to estimate the combining ability of cauliflower breeding lines. The experiment comprised 38 genotypes, 36 hybrids from a partial diallel cross obtained by crosses between two groups of cauliflower lines: Group I ( 3 parents) and Group II (12 parents) and 2 commercial controls. We evaluated plant cycle, resistance to diseases, average curd mass, curd color, hollow stalk incidence, and overall evaluation. Additive genetic effects were more important than non-additive effects in the expression of these traits. No single parental line showed simultaneously the most favorable GCA values for all traits. The most promising hybrids were the combinations BR1 x TE6, BR1 x TE8, BR1 x TE12, BR2 x TE11, BR3 x TE6 and BR3 x TE7. The results of the choice of hybrids made by the method of independent culling levels reflect what it could be predicted by estimating GCA for cycle and average mass of the curd, reaffirming the importance of additive effects in the expression of these traits.
\end{abstract}

Keywords: Brassica oleracea var. botrytis, cauliflower breeding, diallel analysis, partial diallel, independent culling levels.

\section{RESUMO}

Capacidade geral e específica de combinação em couve-flor de inverno

Poucas cultivares brasileiras de couve-flor têm se mostrado adaptadas às condições de inverno. Além disso, estudos sobre a obtenção de híbridos adaptados às nossas condições de inverno, a partir de linhagens oriundas de regiões tropicais, são escassos. Assim, objetivou-se estimar a capacidade combinatória de linhagens de couve-flor. $\mathrm{O}$ experimento constituiu-se de 38 genótipos, sendo 36 híbridos oriundos de um dialelo parcial, obtidos por cruzamentos entre dois grupos de linhagens: grupo I (três genitores) e grupo II (12 genitores) e duas testemunhas comerciais. Foram avaliados o ciclo, resistência a doenças, massa média da cabeça, cor da cabeça, presença de talo oco e avaliação geral. Os efeitos gênicos aditivos foram mais importantes do que os não-aditivos na expressão das características avaliadas. Nenhum parental apresentou concomitantemente os efeitos de Capacidade Geral de Combinação (GCA) mais favoráveis para todas as características avaliadas. Os híbridos experimentais mais promissores foram BR1 x TE6, BR1 x TE8, BR1 x TE12, BR2 x TE11, BR3 x TE6 e BR3 x TE7. Os resultados da escolha de híbridos, feita pelo critério de níveis independentes de eliminação, refletiram em grande parte o que se poderia prever através das estimativas de GCA para as características ciclo e massa média da cabeça, reafirmando a importância dos efeitos aditivos na expressão destas características.

Palavras-chave: Brassica oleracea var. botrytis, melhoramento de brássicas, análise dialélica, dialelo parcial, níveis independentes de eliminação.

Received on July 1, 2015; accepted on August 2, 2016

$\mathrm{C}$ auliflower (Brassica oleracea var. botrytis) is one of the most consumed vegetable in Brazil. According to data reported by the Food and Agriculture Organization of the United Nations (2016), the world production of cauliflower and broccoli was about 20 million tons, in 2013. In Brazil, according to data from CONAB (2016), the cauliflower production was close to 80 thousand tons, in 2015.

According to Branca (2008), the cultivars are classified mainly when curds are harvested, in summer and winter cauliflower. Winter cultivars require accumulation of more hours of cold, below the base temperature, when compared to summer cultivars. The cultivars adapted to tropical growing conditions were originally selected in India, at about 200 years ago, from British biennial cauliflower (Dixon \& Dickson, 2007). In Brazil, these cultivars originated from the pioneering work carried out by Marcílio Dias in the 1940s and Hiroshi Ikuta in the early 1960 s, and more recently from the breeding program established by Sakata

\section{Seed Sudamerica.}

The winter cauliflower cultivars, destined to the Brazilian market, need to tolerate large fluctuations in temperature and relative humidity. These weather conditions favor the appearance of several foliar diseases (downy mildew and bacterioses) and various physiological defects in curds (hollow stalk, purple curds and presence of hair and bracts). The current hybrids produced in the breeding program in Brazil show resistance to main foliar diseases and adaptation to winter 
cultivation; however, they present low quality of curds (firmness, low-weight, yellow curds). On the other hand, the germplasm from temperate regions produce good quality curds (firm, heavy and white curds), although it is very susceptible to main foliar diseases and physiological defects (hollow stalk, purple curd with hair and bracts).

The study, carried out by Varalakshmi (2009) reports that compact, white, medium size, free of defects or diseases and highly productive curds are desirable traits in a cauliflower crop. Saha et al. (2015) state that curd color is determined by one single gene, being the white color a recessive character. Precocity in cauliflower is described by additive and dominant genetic action, whereas late cycle is considered recessive and polygenic (Sharma et al, 2005; Varalakshmi \& Savithramma, 2010).

Few Brazilian cauliflower cultivars have shown to be adapted to winter conditions. Moreover, studies on obtaining hybrids adapted to our winter conditions, from breeding lines from tropical regions, are scarce. In this context, the aim of this research was to estimate combining ability of cauliflower breeding lines potentially usable as hybrid parents for winter crop, in order to identify promising combinations to select genotypes with similar or superior qualities than those current marketable hybrids.

\section{MATERIAL AND METHODS}

The experiment was carried out at Estação Experimental de Bragança Paulista, belonging to Sakata Seed Sudamerica, located in the municipality of Bragança Paulista, in the state of São Paulo. The genetic material consisted of 36 experimental hybrids, corresponding to a partial diallelic scheme, and two commercial controls, Juliana (hybrid from Sakata Corporation) and Flamenco (hybrid from Bejo Companies); both cultivars have shown to be adapted to winter conditions.

Partial diallel was obtained through the cross of two groups of breeding lines. The genotypes of group I comprised three elite lines, malesterile, identified as BR1, BR2 and BR3 (female parentals). These lines show good adaptation to winter conditions, which present large fluctuations in temperature and relative humidity, prevalent in Brazil. Group II consisted of twelve fertile lines (male parents) selected through pedigree method, from bi-parental winter cauliflower populations, from temperate regions in Europe, named from TE1 to TE12. These lines are results from three populations: population 1 (parents from TE1 to TE3); population 2 (parent TE4); and population 3 (parents from TE5 to TE12) (Table 1). Both groups I and II were developed at Estação Experimental de Bragança Paulista belonging to Sakata Seed Sudamerica, in Bragança Paulista.

The treatments were sown in April, 2013 (autumn), to be harvested and evaluated in August, 2013 (winter). Sowing was carried out in 128-cell styrofoam trays, containing commercial substrate Tropstrato ${ }^{\circledR}$. After 30 days, seedlings were transplanted to the field, spacing $70 \mathrm{~cm}$ between lines and $50 \mathrm{~cm}$ between plants, equivalent to 28,571 plants/ha.

Fertilization at planting and top dressing were carried out according to May et al. (2007) for cauliflower crop. The fertilization at planting consisted of $60 \mathrm{~kg} / \mathrm{ha}$ of nitrogen, $400 \mathrm{~kg} / \mathrm{ha}$ of $\mathrm{P}_{2} \mathrm{O}_{5}$ and $180 \mathrm{~kg} / \mathrm{ha}$ of $\mathrm{K}_{2} \mathrm{O}$. Top dressing application was carried out using 180 $\mathrm{kg} / \mathrm{ha}$ of $\mathrm{N}$ and $90 \mathrm{~kg} / \mathrm{ha}$ of $\mathrm{K}_{2} \mathrm{O}$, divided into three applications, every 15 days, after seedling transplanting.

Hybrids were evaluated as they reached harvesting time, which is determined by the maximum size the curd reaches, without apparent deformation caused by damping-off. To select the most promising hybrids, the authors used the method of independent culling levels, described by Ramalho et al. (2012). The authors selected hybrids showing cycle equal or shorter than 120 days and with average curd mass higher than $1,5 \mathrm{~kg}$.

The following traits were evaluated: a) cycle (number of days from sowing until the beginning of harvesting); b) resistance to diseases [score for resistance to diseases like bacterioses caused by Xanthomonas spp. and/or Pseudomonas spp., downy mildew (Peronospora parasitica) and Alternaria leaf spot (Alternaria spp.). These diseases were evaluated through a score using a scale from 1(susceptible) to 5 (resistant)]; c) average curd mass (expressed in grams, and referred to, only, floral primordia mass, without leaves); d) curd color [evaluated using a scale from 1 (yellow, undesirable) to 5 (white, desirable)]; e) hollow stalk [evaluated through a scale from 1 (present, undesirable) to 5 (absent, desirable)]; f) overall evaluation [general evaluation of the hybrids, score between 1 (very bad) to 5 (very good)]. The authors considered positive aspects of the hybrid like resistance to diseases, tolerance to thermal oscillations, tolerance to hollow stalk, upright, vigorous plants, with leaves which protected inflorescences, light color inflorescences, higher mass and greater compactness.

Analysis of variance and $F$ test were carried out for each of the traits evaluated. The randomized block design with three replications was used, eight plants per plot, totalizing 912 plants, using the statistical program $\mathrm{R}$ ( $\mathrm{R}$ Foundation for Statistical Computing, 2013). Evaluations were carried out daily until the end of the experiment. The authors used Scott-Knott test to verify the differences between the treatments, using computer program Genes (Cruz, 2013).

In diallelic analysis, which considered only the hybrids, average squares and estimates of general combining ability (GCA) and specific combining ability (SCA), in each trait evaluated, were obtained. The authors used Griffing's method 4 (1956) adapted for partial diallels (Cruz et al., 2012), being the statistical model $\mathrm{Yij}=\mu+\mathrm{gi}+$ $\mathrm{gj}+\mathrm{sij}+\mathrm{eij}$, in which Yij: observation of hybrid combination between i-th parent of group I and $j$-th parent of group II; $\mu$ : overall average; gi: general combining ability of i-th parent of group I; gj: general combining ability of $j$-th parent of group II; sij: specific combining ability between $i$ and $j$ parents, of groups I and II; eij: experimental error. Diallelic analysis was carried out using program Genes (Cruz, 2013) and the following 
restrictions were adopted to obtain the estimates (Cruz et al., 2012): $\sum \mathrm{gi}=0$ (I $=1,2, \ldots, p) ; \sum$ gj $=0(j=1,2, \ldots, q)$; $\sum \mathrm{sij}=0$.

In order to verify the contribution of genetic effects, the authors calculated the determination coefficient $\left(\mathrm{R}^{2}\right)$ for estimates of additive effects (GCA) and non-additive effects (SCA) and sum of squares of treatments, for each trait studied (Ramalho et al., 1993).

\section{RESULTS AND DISCUSSION}

The mean square analysis of the treatments showed significant differences $(\mathrm{p}<0.05)$ among genotypes of the partial diallel for cycle, average mass and curd color, evaluated by F test (Table 2). The estimates of GCA for parents of group I were significant $(\mathrm{p}<0.05)$ for all variableresponses studied, except for the overall evaluation, showing that lines BR1, BR2 and BR3 are quite divergent for these traits and that additive genetic effects are important in their expressions (Table 2). Likewise, for lines of group II, in which the estimates of GCA were significant $(\mathrm{p}<0.05)$ for plant cycle, resistance to diseases, average mass and curd color. The estimate of GCA of a parent is an important indicator of its potential for generating superior populations. A high estimate of GCA shows that the average of the parent is inferior or superior to overall average. This represents a strong evidence of favorable gene flow of the parent for the progeny at a high frequency and informs on the predominantly additive genetic concentration (Franco et al., 2001).

The study of combining ability in cauliflower, carried out by Lal et al. (1977), showed magnitude of general combining ability higher than specific combining ability for all the traits studied. The work carried out by $\mathrm{Li}$ et al. (2013), which also evaluated the combining ability in cauliflower, concluded that the additive effects were significant for the most traits studied.

The analysis of SCA is an important parameter to choose specific combinations to exploit heterosis. Good cross combinations are selected based on their effects (Verma \& Kalia, 2015). Specific combining ability and, therefore, non-additive genetic effects were important $(p<0,05)$ for expressing plant cycle and average mass of the curd; however, the authors did not notice any significant differences for the other traits. Even for these significant cases, although SCA showed to be

Table 1. Description of the hybrid parents tested in partial diallel. Bragança Paulista, Sakata Seed Sudamerica, 2013.

\begin{tabular}{|c|c|c|c|c|c|c|}
\hline \multirow[b]{2}{*}{ Parentals } & \multicolumn{3}{|c|}{ Plant characteristics } & \multicolumn{3}{|c|}{ Curd characteristics } \\
\hline & Cycle & $\begin{array}{c}\text { Resistance to } \\
\text { diseases }\end{array}$ & Color & Mass & Size & $\begin{array}{l}\text { Hollow stalk } \\
\text { incidence }\end{array}$ \\
\hline BR1 & late & high & cream & light & regular & low \\
\hline BR2 & late & high & yellow & light & large & low \\
\hline BR3 & intermediate & high & cream & light & regular & low \\
\hline TE1 to TE3 & early & low & cream & heavy & regular & high \\
\hline TE4 & intermediate & regular & white & heavy & regular & regular \\
\hline TE5 to TE12 & late & low & white & heavy & regular & high \\
\hline
\end{tabular}

Plant cycle: early plants are desired; Resistance to diseases: high level is desired; Curd color: white color is desired; Curd mass: heavy curds are desired; Curd size: larger curd size is desired; Hollow stalk incidence (boron deficiency): low level is desired.

Table 2. Analysis of variance of combining ability in partial diallel among cauliflower breeding lines. Bragança Paulista, Sakata Seed Sudamerica, 2013.

\begin{tabular}{|c|c|c|c|c|c|c|c|c|c|c|c|}
\hline \multirow{3}{*}{$\begin{array}{l}\text { Variance factors } \\
\text { Treatments }\end{array}$} & \multirow{3}{*}{$\begin{array}{c}\text { GL } \\
35\end{array}$} & \multicolumn{10}{|c|}{ Mean squares } \\
\hline & & \multicolumn{2}{|l|}{ Cycle } & \multicolumn{2}{|c|}{$\begin{array}{l}\text { Resistance } \\
\text { to diseases }\end{array}$} & \multicolumn{2}{|c|}{$\begin{array}{c}\text { Average curd } \\
\text { weight }\end{array}$} & \multicolumn{2}{|c|}{ Curd color } & $\begin{array}{l}\text { Hollow } \\
\text { stalk }\end{array}$ & $\begin{array}{c}\text { General } \\
\text { evaluation }\end{array}$ \\
\hline & & 35.660 & $*$ & 0.334 & ns & 141022.638 & $*$ & 0.411 & $*$ & $2.110 \mathrm{~ns}$ & $0.546 \mathrm{~ns}$ \\
\hline C.G.C. G-I & 2 & 339.273 & $*$ & 0.827 & $*$ & 265731.278 & $*$ & 1.839 & $*$ & $14.197 *$ & $2.525 \mathrm{~ns}$ \\
\hline C.G.C. G-II & 11 & 35.390 & $*$ & 0.517 & $*$ & 292975.300 & $*$ & 0.558 & $*$ & $1.846 \mathrm{~ns}$ & $0.655 \mathrm{~ns}$ \\
\hline C.E.C. IxII & 22 & 8.193 & $*$ & 0.198 & ns & 53709.159 & $*$ & 0.208 & $\mathrm{~ns}$ & $1.144 \mathrm{~ns}$ & $0.311 \mathrm{~ns}$ \\
\hline Residue & 74 & 4.418 & & 0.249 & & 27666.233 & & 0.138 & & 3.600 & 4.600 \\
\hline$R^{2}(\%) C G C$ & - & 85.55 & & 62.79 & & 76.06 & & 68.23 & & 65.94 & 64.12 \\
\hline$R^{2}(\%) C E C$ & - & 14.44 & & 37.26 & & 23.93 & & 31.81 & & 34.07 & 35.80 \\
\hline CV (\%) & - & 1.767 & & 12.19 & & 11.002 & & 9.424 & & 11.908 & 16.348 \\
\hline
\end{tabular}

ns and *: not significant and significant by $\mathrm{F}$ test $(\mathrm{p}<0.05)$. 
important, as indicated by the magnitude of the determination coefficient, it showed to be less important than GCA effects, though (Table 2). Studying combining ability (Verma \& Kalia, 2015), the authors concluded that most of specific crosses, in which parents showed high GCA, indicated the role of cumulative effect of additive genetic action. However, the study of combining ability in cauliflower carried out by Dixit et al. (2004) concluded that even though both parents have low CGA, the hybrids generated can show high SCA.
The authors verified, through determination coefficient, that predominance of additive genetic effects can be noticed for all the traits in which significant differences were observed and that hybrid results can be inferred largely from the characteristics of their

Table 3. Estimates of the effects of specific combining ability (SCA) among parents of groups I and II. Bragança Paulista, Sakata Seed Sudamerica, 2013.

\begin{tabular}{|c|c|c|c|c|c|c|}
\hline SCA & Cycle & $\begin{array}{c}\text { Resistance to } \\
\text { diseases }\end{array}$ & $\begin{array}{l}\text { Average curd } \\
\text { weight }\end{array}$ & Curd color & Hollow stalk & $\begin{array}{c}\text { General } \\
\text { evaluation }\end{array}$ \\
\hline BR1 x TE1 & -1.93 & 0.015 & 92.02 & 0.271 & -0.152 & 0.140 \\
\hline BR1 x TE2 & -0.38 & 0.131 & 157.68 & -0.065 & -0.143 & -0.265 \\
\hline BR1 x TE3 & -0.51 & 0.126 & -24.12 & -0.089 & -0.267 & -0.390 \\
\hline BR1 x TE4 & 0.22 & 0.154 & -10.89 & 0.126 & -0.267 & 0.141 \\
\hline BR1 x TE5 & 1.09 & 0.029 & 57.05 & -0.015 & 0.699 & 0.293 \\
\hline BR1 x TE6 & -0.33 & 0.180 & -154.01 & -0.104 & 0.234 & -0.050 \\
\hline BR1 x TE7 & 2.27 & 0.152 & -39.07 & -0.023 & 0.155 & 0.166 \\
\hline BR1 x TE8 & -1.25 & 0.066 & 105.38 & -0.060 & 0.317 & 0.135 \\
\hline BR1 x TE9 & -0.18 & -0.428 & -107.23 & 0.094 & -0.036 & 0.062 \\
\hline BR1 x TE10 & 1.85 & -0.122 & -48.56 & 0.456 & -0.225 & 0.114 \\
\hline BR1 x TE11 & -1.00 & -0.167 & -73.78 & -0.466 & -0.223 & -0.446 \\
\hline BR1 x TE12 & 0.16 & -0.134 & 45.53 & -0.126 & -0.090 & 0.100 \\
\hline BR2 x TE1 & 1.32 & -0.382 & -60.40 & 0.262 & 0.487 & 0.272 \\
\hline BR2 x TE2 & -1.13 & -0.351 & -123.94 & 0.032 & 0.605 & 0.144 \\
\hline BR2 $\times$ TE3 & -1.33 & 0.038 & -82.67 & -0.089 & 0.717 & -0.207 \\
\hline BR2 $\times$ TE4 & -1.99 & 0.093 & -21.78 & -0.217 & 0.717 & 0.197 \\
\hline BR2 x TE5 & 0.47 & -0.099 & -105.00 & 0.246 & -1.383 & -0.601 \\
\hline BR2 x TE6 & -0.08 & -0.029 & -22.89 & 0.053 & -0.420 & 0.257 \\
\hline BR2 $\times$ TE7 & 1.18 & 0.013 & -131.09 & -0.009 & -0.262 & -0.106 \\
\hline BR2 x TE8 & 1.66 & -0.218 & -80.17 & 0.035 & -0.857 & -0.166 \\
\hline BR2 $\times$ TE9 & 1.27 & 0.319 & 223.55 & 0.014 & 0.022 & -0.010 \\
\hline BR2 $\times$ TE10 & -1.30 & 0.214 & 132.89 & -0.450 & -0.483 & -0.194 \\
\hline BR2 $x$ TE11 & -0.22 & 0.407 & 183.66 & 0.056 & 0.628 & 0.400 \\
\hline BR2 $\times$ TE12 & 0.14 & -0.006 & 87.84 & 0.067 & 0.229 & 0.013 \\
\hline BR3 $\times$ TE1 & 0.61 & 0.368 & -31.61 & -0.533 & -0.335 & -0.413 \\
\hline BR3 x TE2 & 1.50 & 0.220 & -33.75 & 0.033 & -0.461 & 0.121 \\
\hline BR3 $\times$ TE3 & 1.84 & -0.164 & 106.79 & 0.177 & -0.450 & 0.597 \\
\hline BR3 $\times$ TE4 & 1.77 & -0.247 & 32.68 & 0.091 & -0.450 & -0.338 \\
\hline BR3 $x$ TE5 & -1.56 & 0.070 & 47.95 & -0.231 & 0.684 & 0.308 \\
\hline BR3 x TE6 & 0.41 & -0.151 & 176.90 & 0.051 & 0.186 & -0.208 \\
\hline BR3 $\times$ TE7 & -3.45 & -0.164 & 170.16 & 0.032 & 0.107 & -0.060 \\
\hline BR3 $\times$ TE8 & -0.41 & 0.152 & -25.21 & 0.026 & 0.540 & 0.030 \\
\hline BR3 $\times$ TE9 & -1.10 & 0.109 & -116.33 & -0.108 & 0.015 & -0.053 \\
\hline BR3 $\times$ TE10 & -0.54 & -0.092 & -84.32 & -0.007 & 0.708 & 0.080 \\
\hline BR3 $x$ TE11 & 1.21 & -0.240 & -109.88 & 0.410 & -0.406 & 0.047 \\
\hline BR3 $x$ TE12 & -0.30 & 0.140 & -133.37 & 0.058 & -0.139 & -0.113 \\
\hline
\end{tabular}


Table 4. Estimates of the effects of general combining ability for parentals of groups I and II. Bragança Paulista, Sakata Seed Sudamerica, 2013.

\begin{tabular}{|c|c|c|c|c|c|c|}
\hline Parentals & Cycle & $\begin{array}{c}\text { Resistance to } \\
\text { diseases }\end{array}$ & $\begin{array}{l}\text { Average curd } \\
\text { weight }\end{array}$ & Curd color & Hollow stalk & $\begin{array}{c}\text { General } \\
\text { evaluation }\end{array}$ \\
\hline $\boldsymbol{\mu}$ (medium) & 118.806 & 4.068 & 1505.633 & 3.926 & 4.530 & 3.316 \\
\hline \multicolumn{7}{|c|}{ GCA-group I } \\
\hline BR1 & 0.665 & -0.087 & -41.438 & -0.057 & 0.267 & 0.246 \\
\hline BR2 & 2.682 & -0.087 & 98.780 & 0.249 & -0.717 & 0.033 \\
\hline BR3 & -3.348 & 0.175 & -57.341 & -0.191 & 0.450 & -0.280 \\
\hline \multicolumn{7}{|c|}{ GCA-group II } \\
\hline TE1 & -1.473 & 0.184 & -134.677 & -0.373 & 0.354 & -0.370 \\
\hline TE2 & -2.095 & 0.081 & -240.211 & -0.342 & 0.345 & -0.232 \\
\hline TE3 & -2.228 & -0.223 & -344.744 & -0.289 & 0.469 & -0.478 \\
\hline TE4 & -0.162 & 0.320 & -94.966 & 0.029 & 0.469 & 0.408 \\
\hline TE5 & 5.104 & -0.615 & -10.244 & 0.443 & -0.765 & 0.204 \\
\hline TE6 & -0.873 & 0.032 & 278.144 & 0.266 & -0.166 & 0.170 \\
\hline TE7 & 0.193 & 0.064 & 227.877 & 0.095 & -0.087 & 0.051 \\
\hline TE8 & 0.915 & -0.131 & 58.422 & 0.082 & -0.520 & -0.111 \\
\hline TE9 & 0.571 & 0.030 & 17.366 & 0.035 & 0.004 & 0.337 \\
\hline TE10 & 0.949 & 0.069 & 48.700 & 0.204 & -0.688 & -0.032 \\
\hline TE11 & -1.539 & 0.178 & 95.255 & -0.039 & 0.425 & -0.050 \\
\hline TE12 & 0.638 & 0.009 & 99.077 & -0.110 & 0.158 & 0.103 \\
\hline
\end{tabular}

parental lines (Table 2). However, Dey et. al. (2014), studying combining ability and heterosis in cauliflower for vitamins and antioxidant pigments, concluded that SCA was more important than GCA when obtaining hybrids with higher contents of vitamins and antioxidant.

Actually, deviations related to SCA for cycle, with only two exceptions (for hybrids BR3 x TE7 and BR1 x TE7), were lower in magnitude in two days. SCA presented magnitude lower than $150 \mathrm{~g} /$ curd for average mass of curd, with exception for six hybrids (BR1 $x$ TE2, BR1 x TE6, BR2 x TE9, BR2 x TE11, BR3 x TE6, BR3 x TE7) (Table $3)$.

No parent showed simultaneously the most favorable GCA effects for all traits evaluated (Table 4). Showing that recombination among the best lines, within each group, may produce superior lines in the future, as described by several authors when studying combining ability in cauliflowers in diallelic analyses (Lal et al., 1977; Dixit et al., 2004; Li et al., 2013).
The cauliflower hybrids F1 are becoming more popular each day, since they are uniform, they show to have broad adaptability and availability all year long (Sharma et al., 2005). The authors expect that one hybrid from the lines of these two groups is able to show characteristics like high-vigor plant, medium or large leaves, medium or high resistance to diseases and high protection for the curd. The curds should have light color, medium or large mass, medium size, high tolerance to climatic oscillations and low incidence of hollow stalk. Using the method of independent culling levels (Ramalho et al., 2012) to select the most promising hybrids, the authors had chosen hybrids showing cycle equal or shorter than 120 days and with average curd mass higher than 1,5 $\mathrm{kg}$. The following hybrid combinations stood out: BR1 x TE6, BR1 x TE8, BR1 $x$ TE12, BR2 $x$ TE11, BR3 $x$ TE6 and BR3 x TE7 (Table 5).

Of these six hybrids, which showed both shortest cycle and highest average mass of curd, all of them presented as parents of group I lines with GCA values for precocity, close to zero (BR1) or negative (BR3), or even with GCA values, for average mass of curd, quite positive (BR2) (Table 4). All of them also showed, as parents of group II, parental lines with GCA values negative or close to zero (TE6, TE7, TE11) for cycle and/or with values more positive for average mass of curd (TE6, TE7, TE8, TE11, TE12) (Table 4).

Thus, the results of hybrid choice which was carried out using the method of independent culling levels largely reflected what could be predicted through GCA estimates for cycle and average mass of curd, reaffirming the importance of additive genetic effects in the expression for these traits.

\section{ACKNOWLEDGEMENT}

To Sakata Seed Sudamerica for the concession of the area, inputs, labor and material availability, and to Universidade Federal de Lavras for knowledge and support on writing this paper. 
Table 5. Averages obtained for six traits evaluating controls (cultivars) and hybrids by Scott-Knott test. Bragança Paulista, Sakata Seed Sudamerica, 2013.

\begin{tabular}{|c|c|c|c|c|c|c|}
\hline Cultivars/hybrids & Cycle (days) & $\begin{array}{c}\text { Resistance to } \\
\text { diseases }^{1}\end{array}$ & $\begin{array}{c}\text { Average curd } \\
\text { weight (kg) }\end{array}$ & Curd color ${ }^{2}$ & Hollow stal ${ }^{3}$ & $\begin{array}{c}\text { General } \\
\text { evaluation }\end{array}$ \\
\hline Juliana & $123 b$ & $4.57 \mathrm{a}$ & $1.68 \mathrm{~b}$ & $4.20 \mathrm{a}$ & $5.00 \mathrm{a}$ & $4.61 \mathrm{a}$ \\
\hline Flamenco & $120 \mathrm{c}$ & $4.00 \mathrm{a}$ & $1.56 \mathrm{~b}$ & $4.02 \mathrm{a}$ & $4.59 \mathrm{a}$ & $4.30 \mathrm{a}$ \\
\hline BR1 x TE1 & $116 \mathrm{~d}$ & $4.18 \mathrm{a}$ & $1.42 \mathrm{c}$ & $3.77 \mathrm{~b}$ & $5.00 \mathrm{a}$ & $3.33 b$ \\
\hline BR1 x TE2 & $117 \mathrm{~d}$ & $4.19 \mathrm{a}$ & $1.38 \mathrm{c}$ & $3.46 \mathrm{~b}$ & $5.00 \mathrm{a}$ & $3.07 \mathrm{~b}$ \\
\hline BR1 x TE3 & $117 d$ & $3.88 \mathrm{a}$ & $1.10 \mathrm{~d}$ & $3.49 b$ & $5.00 \mathrm{a}$ & $2.69 \mathrm{~b}$ \\
\hline BR1 x TE4 & $120 \mathrm{c}$ & $4.46 \mathrm{a}$ & $1.36 \mathrm{c}$ & $4.03 \mathrm{a}$ & $5.00 \mathrm{a}$ & $4.11 \mathrm{a}$ \\
\hline BR1 x TE5 & $126 a$ & $3.39 \mathrm{a}$ & $1.51 \mathrm{c}$ & $4.30 \mathrm{a}$ & $4.73 a$ & $4.06 \mathrm{a}$ \\
\hline BR1 x TE6 & $118 \mathrm{~d}$ & $4.19 \mathrm{a}$ & $1.59 b$ & $4.03 \mathrm{a}$ & $4.86 \mathrm{a}$ & $3.68 \mathrm{a}$ \\
\hline BR1 x TE7 & $122 b$ & $4.20 \mathrm{a}$ & $1.65 b$ & $3.94 \mathrm{a}$ & $4.86 \mathrm{a}$ & $3.78 \mathrm{a}$ \\
\hline BR1 x TE8 & $119 \mathrm{c}$ & $3.91 \mathrm{a}$ & $1.63 b$ & $3.89 \mathrm{a}$ & $4.59 \mathrm{a}$ & $3.59 \mathrm{a}$ \\
\hline BR1 x TE9 & $120 \mathrm{c}$ & $3.58 \mathrm{a}$ & $1.37 \mathrm{c}$ & $4.00 \mathrm{a}$ & $4.77 \mathrm{a}$ & $3.96 \mathrm{a}$ \\
\hline BR1 x TE10 & $122 b$ & $3.93 \mathrm{a}$ & $1.46 \mathrm{c}$ & $4.53 \mathrm{a}$ & $3.88 \mathrm{~b}$ & $3.64 \mathrm{a}$ \\
\hline BR1 $x$ TE11 & $117 d$ & $3.99 \mathrm{a}$ & $1.49 \mathrm{c}$ & $3.36 \mathrm{~b}$ & $5.00 \mathrm{a}$ & $3.07 \mathrm{~b}$ \\
\hline BR1 x TE12 & $120 \mathrm{c}$ & $3.86 \mathrm{a}$ & $1.61 \mathrm{~b}$ & $3.63 b$ & $4.87 \mathrm{a}$ & $3.77 \mathrm{a}$ \\
\hline BR2 $\times$ TE1 & $121 \mathrm{c}$ & $3.78 \mathrm{a}$ & $1.41 \mathrm{c}$ & $4.06 \mathrm{a}$ & $4.65 \mathrm{a}$ & $3.25 \mathrm{~b}$ \\
\hline BR2 $\times$ TE2 & $118 \mathrm{~d}$ & $3.71 \mathrm{a}$ & $1.24 \mathrm{~d}$ & $3.86 \mathrm{a}$ & $4.76 \mathrm{a}$ & $3.26 \mathrm{~b}$ \\
\hline $\mathrm{BR} 2 \times \mathrm{TE} 3$ & $118 \mathrm{~d}$ & $3.80 \mathrm{a}$ & $1.18 \mathrm{~d}$ & $3.80 \mathrm{~b}$ & $5.00 \mathrm{a}$ & $2.67 \mathrm{~b}$ \\
\hline BR2 $x$ TE4 & $119 \mathrm{c}$ & $4.40 \mathrm{a}$ & $1.49 \mathrm{c}$ & $3.99 \mathrm{a}$ & $5.00 \mathrm{a}$ & $3.96 \mathrm{a}$ \\
\hline BR2 $x$ TE5 & $127 \mathrm{a}$ & $3.27 \mathrm{a}$ & $1.49 \mathrm{c}$ & $4.86 \mathrm{a}$ & $1.66 \mathrm{c}$ & $2.95 \mathrm{~b}$ \\
\hline BR2 $\times$ TE6 & $121 \mathrm{c}$ & $3.99 \mathrm{a}$ & $1.86 \mathrm{a}$ & $4.50 \mathrm{a}$ & $3.23 b$ & $3.78 \mathrm{a}$ \\
\hline BR2 x TE7 & $123 b$ & $4.06 \mathrm{a}$ & $1.70 \mathrm{~b}$ & $4.26 \mathrm{a}$ & $3.46 \mathrm{~b}$ & $3.30 \mathrm{~b}$ \\
\hline BR2 $\times$ TE8 & $124 \mathrm{~b}$ & $3.63 \mathrm{a}$ & $1.58 \mathrm{~b}$ & $4.29 \mathrm{a}$ & $2.44 \mathrm{c}$ & $3.07 \mathrm{~b}$ \\
\hline BR2 x TE9 & $123 b$ & $4.33 \mathrm{a}$ & $1.85 \mathrm{a}$ & $4.22 \mathrm{a}$ & $3.84 b$ & $3.68 \mathrm{a}$ \\
\hline BR2 $\times$ TE10 & $121 \mathrm{c}$ & $4.27 \mathrm{a}$ & $1.79 \mathrm{a}$ & $3.93 \mathrm{a}$ & $2.64 \mathrm{c}$ & $3.12 b$ \\
\hline BR2 $\times$ TE11 & $120 \mathrm{c}$ & $4.57 \mathrm{a}$ & $1.88 \mathrm{a}$ & $4.19 \mathrm{a}$ & $4.87 \mathrm{a}$ & $3.70 \mathrm{a}$ \\
\hline BR2 x TE12 & $122 b$ & $3.99 \mathrm{a}$ & $1.79 \mathrm{a}$ & $4.13 \mathrm{a}$ & $4.20 \mathrm{a}$ & $3.47 \mathrm{a}$ \\
\hline BR3 X TE1 & $115 d$ & $4.80 \mathrm{a}$ & $1.28 \mathrm{~d}$ & $2.83 b$ & $5.00 \mathrm{a}$ & $2.25 \mathrm{~b}$ \\
\hline BR3 X TE2 & $115 d$ & $4.55 \mathrm{a}$ & $1.17 \mathrm{~d}$ & $3.43 \mathrm{~b}$ & $4.86 a$ & $2.92 \mathrm{~b}$ \\
\hline BR3 X TE3 & $115 \mathrm{~d}$ & $3.86 \mathrm{a}$ & $1.21 \mathrm{~d}$ & $3.62 b$ & $5.00 \mathrm{a}$ & $3.16 \mathrm{~b}$ \\
\hline BR3 X TE4 & $117 d$ & $4.32 \mathrm{a}$ & $1.39 \mathrm{c}$ & $3.86 \mathrm{a}$ & $5.00 \mathrm{a}$ & $3.11 \mathrm{~b}$ \\
\hline BR3 X TE5 & $119 \mathrm{c}$ & $3.70 \mathrm{a}$ & $1.49 \mathrm{c}$ & $3.95 \mathrm{a}$ & $4.90 \mathrm{a}$ & $3.55 \mathrm{a}$ \\
\hline BR3 X TE6 & $115 \mathrm{~d}$ & $4.13 \mathrm{a}$ & $1.90 \mathrm{a}$ & $4.05 \mathrm{a}$ & $5.00 \mathrm{a}$ & $3.00 \mathrm{~b}$ \\
\hline BR3 X TE7 & $112 d$ & $4.14 \mathrm{a}$ & $1.85 \mathrm{a}$ & $3.86 \mathrm{a}$ & $5.00 \mathrm{a}$ & $3.03 \mathrm{~b}$ \\
\hline BR3 X TE8 & $116 \mathrm{~d}$ & $4.26 \mathrm{a}$ & $1.48 \mathrm{c}$ & $3.84 \mathrm{a}$ & $5.00 \mathrm{a}$ & $2.96 \mathrm{~b}$ \\
\hline BR3 X TE9 & $115 d$ & $4.38 \mathrm{a}$ & $1.35 \mathrm{c}$ & $3.66 \mathrm{~b}$ & $5.00 \mathrm{a}$ & $3.32 \mathrm{~b}$ \\
\hline BR3 X TE10 & $116 \mathrm{~d}$ & $4.22 \mathrm{a}$ & $1.41 \mathrm{c}$ & $3.93 \mathrm{a}$ & $5.00 \mathrm{a}$ & $3.08 \mathrm{~b}$ \\
\hline BR3 X TE11 & $115 d$ & $4.18 \mathrm{a}$ & $1.43 \mathrm{c}$ & $4.10 \mathrm{a}$ & $5.00 \mathrm{a}$ & $3.03 \mathrm{~b}$ \\
\hline BR3 X TE12 & $116 \mathrm{~d}$ & $4.39 \mathrm{a}$ & $1.41 \mathrm{c}$ & $3.68 \mathrm{~b}$ & $5.00 \mathrm{a}$ & $3.03 \mathrm{~b}$ \\
\hline
\end{tabular}

$1=$ evaluated through a scale varying from 1 (susceptible) to 5 (resistant); $2=$ evaluated through a scale varying from 1 (yellow) to 5 (white); $3=$ evaluated through a scale varying from 1 (susceptible) to 5 (resistant); $3=$ evaluated through a scale varying from 1 (present) to 5 (absent); $4=$ evaluated through a scale varying from 1 (very bad) to 5 (very good). Averages followed by the same letter in column did not differ significantly from each other, Scott-Knott, $\mathrm{p}<0.05$.

\section{REFERENCES}

BRANCA, F. 2008. Cauliflower and Broccoli.
In: PROHENS, J; NUEZ, F (eds). Vegetables. New York. p. 151-186.

CONAB - Companhia Nacional de Abastecimento. 2016. Programa Brasileiro de Modernização do Mercado Hortigranjeiro. Disponível em http://dw.prohort.conab.gov.br/pentaho/ Prohort. Accessed on June 4, 2016.

CRUZ, CD. 2013. GENES - a software package 
for analysis in experimental statistics and quantitative genetics. Acta Scientiarum Agronomy 35: 271-276.

CRUZ, CD; REGAZZI, AJ; CARNEIRO, PCS. 2012. Modelos biométricos aplicados ao melhoramento genético. Viçosa: UFV. 514p.

DEY, SS; SINGH, N; BHATIA, R; PARKASH, C; CHANDEL, C. 2014. Genetic combining ability and heterosis for important vitamins and antioxidant pigments in cauliflower (Brassica oleracea var. botrytis L.). Euphytica 195: 169-181.

DIXIT, SK; SINGH, BP; RAM, HH. 2004. Heterosis and combining ability in Indian cauliflower (Brassica oleracea var. botrytis L.). Vegetable Science 31: 164-167.

DIXON, G; DICKSON, M. 2007. Vegetable Brassicas and related Crucifers. CABI. 339p.

FAO - Food and Agriculture Organization of the United Nations - Statistics Division. 2016. 04 de Junho. Disponível em http://faostat3. fao.org/browse/Q/QC/E. Accessed on June 4, 2016.

FRANCO, MC; CASSINI, ST; OLIVEIRA, VR; VIEIRA, C; TSAI, SM; CRUZ, CD. 2001. Combining ability for nodulation in common bean (Phaseolus vulgaris L.) genotypes from
Andean and Middle American gene pools. Euphytica 118:265-270.

GRIFFING, B. 1956. Concept of general and specific combining ability in relation to diallel crossing systems. Australian Journal of Biological Science 9: 463-493.

LAL, G; SWARUP, V; CHATTERJEE, SS. 1977. Combining ability in early Indian cauliflower. Journal of Agricultural Science 89: 169-175.

LI, GQ; XIE, ZJ; YAO, XQ. 2013. Study on combining ability and heritability analysis of main economic characters for cauliflower. Plant Science 31: 143-150.

MAY, A; TIVELLI, SW; VARGAS, PF; SAMRA, AG; SACCONI, LV; PINHEIRO, MQ. 2007. A cultura da couve-flor. Campinas: Instituto Agronômico. 36p (Boletim Técnico IAC, 2000).

R FOUNDATION FOR STATISTICAL COMPUTING. R: a language and environment for statistical computing. 2013. Disponível em: http://www.r-project.org/.

RAMALHO, MAP; ABREU, AFB; SANTOS, JB NUNES, JAR. 2012. Aplicações da genética quantitativa no melhoramento de plantas autógamas. Lavras: UFLA. 522p.

RAMALHO, MAP; SANTOS, JB;
ZIMMERMANN, MJO. 1993. Genética quantitativa em plantas autógamas: aplicações ao melhoramento do feijoeiro. Goiânia: UFG. 271p.

SAHA, P; KALIA, P; JOSHI, S. 2015. Genetic analysis of yield components and curd color of midseason heat tolerant Indian cauliflower (Brassica oleracea var. botrytis L.). SABRAO Journal of Breeding and Genetics 47: 124-132.

SHARMA, SR; SINGH, PK; CHABLE, V; TRIPATHI, SK. 2005. A review of hybrid cauliflower development. Journal of New Seeds 6: 151-193.

VARALAKSHMI B. 2009. Heterosis and combining ability for yield and its components in early cauliflower. Indian Journal of Horticulture 66: 198-203.

VARALAKSHMI, B; SAVITHRAMMA, DL. 2010. Genetics of yield and its component traits in early cauliflower. Indian Journal of Horticulture 67: 339-342.

VERMA, VK; KALIA, P. 2015. Combining ability analysis and its relationship with gene action and heterosis in early maturity cauliflower. Proceedings of the National Academy of Sciences, India Section B: Biological Sciences (published online). 